\title{
STUDI SIMULASI NUMERIK PENGARUH PENAMBAHAN FINS SETENGAH SILINDER DISUSUN SECARA STAGGERED TERHADAP KINERJA KOLEKTOR SURYA PEMANAS UDARA DENGAN PLAT PENYERAP V-CORRUGATED
}

\author{
Sulaiman Ali $^{1)}$ dan Djatmiko Ichsani ${ }^{2)}$ \\ 1) Jurusan Teknik Mesin Universitas Teuku Umar, Meulaboh Aceh Barat \\ 2) Jurusan Teknik Mesin Institut Teknologi Sepuluh Nopember, Surabaya \\ e-mail: ${ }^{1)}$ teungkusulaiman@gmail.com, ${ }^{2)}$ djatmiko@me.its.ac.id
}

\begin{abstract}
The use of solar energy by using solar collector has been extensively researched to optimize existing solar energy source, one of the methods to utilize solar energy is by using solar collector and has been widely utilized by humans in the drying process. To create a solar collector with optimum performance the thermal efficiency needs to be increased, as for increasing the thermal efficiency of solar collector one by extending the absorption field and increasing the convection heat transfer coefficient by creating a turbulent flow inside the solar collector duct, the flow turbulence can be achieved by Provides obstacle and fins disturbance to the flow direction of the working fluid under the hot absorber plate. This research was conducted with $3 D$ Steady flow numerical simulation with turbulence viscos k-omega SST. The objective of this research is to know the optimum diameter and spacing of fins variation with $6 \mathrm{~mm}$, $8 \mathrm{~mm}$, and $10 \mathrm{~mm}$ fins diameter, and variation of fins distance to obstacle 0,25L; 0.5L and 0.75L. The result of numerical simulation optimum fins is determined by the smallest ratio of $\triangle P / \Delta T$ and this research continued to the experiment. The solar collector used in this study is a solar collector using a $v$-corrugated absorber plate with triangular obstacle and half cylindrical fins arranged staggered inside a solar collector duct. The results obtained from this research is, the most optimum half cylinder fins are $6 \mathrm{~mm}$ fins with a fins distance to obstacle $0.75 \mathrm{~L}$.
\end{abstract}

Keywords: absorber, efficiency, fins, solar collector, obstacle, v-corrugated.

\section{PENDAHULUAN}

Kebutuhan energi di dunia ini semakin meningkat, peningkatan kebutuhan energi tersebut sejalan dengan meningkatnya laju pertumbuhan penduduk, ekonomi dan perkembangan teknologi di sektor industri. Ketergantungan Indonesia tehadap bahan bakar fosil sangat besar dan hal ini terlihat dari setiap aktivitas masyarakat Indonesia sehari-hari yang tidak terlepas dari pemakaiaan bahan bakar seperti untuk penerangan, memasak dan transportasi. Bahan bakar fosil merupakan sumber daya alam yang tidak dapat diperbaharui dan semakin hari semakin berkurang [1]. Sampai saat ini Indonesia masih tergantung terhadap energi fosil terutama minyak bumi sebesar 96\% (minyak bumi $48 \%$, gas $18 \%$ dan batu bara sebesar $30 \%$ ) dari hasil total konsumsi energi di Indonesia. Seiring dengan kebutuhan energi yang meningkat, cadangan energi fosil yang tersisa semakin menipis, salah satu sumber energi alternatif yang dapat dipergunakan manusia untuk menjadi solusi dari krisis energi saat ini yaitu energi surya/energi matahari. Energi surya ini dapat dikonversikan menjadi energi panas yang berguna, biasanya digunakan untuk menghasilkan energi listrik (solar cell) atau untuk menghasilkan energi panas yaitu dengan penggunaan solar kolektor, dimana energi panas tersebut dapat digunakan untuk pemanas air, udara dan material lain yang memerlukan pemanasan atau pengeringan. Banyak upaya untuk meningkatkan efisiensi kolektor surya diantaranya yaitu menggunakan plat penyerap yang dicat hitam atau diberi lapisan yang mempunyai absorptance tinggi dan emittance rendah [2]. Untuk meningkatkan koefisien konveksi antara udara dengan plat penyerap adalah dengan mempersempit saluran sehingga aliran menjadi turbulen, mengganti plat penyerap yang umumnya adalah plat datar dengan plat bergelombang $v$-corrugated absorber [3,4]. Meningkatkan koefisien perpindahan panas dari plat ke udara dapat juga dilakukan dengan menambahkan fins atau baffles atau obstacle [5] dalam penelitiannya meneliti tentang obstacle yang berbentuk pin fins dengan beberapa tinggi dan susunan, maka hasil yang didapat adalah semakin rapat dan tinggi fins, maka efisiensi semakin tinggi. Bekele A et al [6] dalam penelitiannya meneliti obstacle berbentuk segitiga yang dipasang diatas plat penyerap dengan beberapa susunan menemukan bahwa semakin rapat dan tinggi obstacle segitiga semakin 
tinggi efisiensi kolektor. Ho.C. D et al [7] meneliti fins yang dipasang diatas dan dibawah plat penyerap dengan diberi aliran recycle. Sedangkan Kulkarni et al [8] melakukan penelitian geometri obstacle yang paling optimum dengan menggunakan Response Surface Approximation (RSA) dan Kriging Models, adapun variabel dari geometri obstacle adalah ratio tinggi obstacle terhadap ketinggian saluran udara, ratio jarak transversal antar obstacle terhadap lebar obstacle dan sudut obstacle yang dikenai udara dan hasil yang diperoleh dari analisa numerik dibandingkan dengan data hasil percobaan, tujuan teknik optimalisasi menggunakan numerik merupakan cara yang efisien untuk meminimalisir perhitungan dan biaya percobaan ketika mendesain solar air heater [9]. Penelitian pada kolektor udara dengan fins yang panjang dan fins kecil-kecil dengan total luasan yang sama dan menemukan bahwa fins yang kecil-kecil menghasilkan efisiensi lebih tinggi. Randall et al [10] meneliti permukaan gelombang bentuk $\mathrm{V}$ dan mengkorelasikan data dalam bilangan Reynolds dan Nusselt. Karim et al [11] melakukan penelitian dengan cara langsung untuk kerja maupun secara teoritis solar kolektor pemanas udara dengan tiga cara plat absorber yang berbeda yaitu absorber plat, absorber plat datar dengan fins dan v-groove (v-corrugated) absorber. Efisiensi kolektor surya dengan $v$-corrugated absorber mempunyai nilai 10-15\% lebih tinggi dari efisiensi kolektor surya dengan absorber plat datar yang mempunyai nilai 5-9\%. Kolektor surya dengan absorber plat datar mempunyai efisiensi yang terkecil dibandingkan dengan kolektor surya absorber plat datar dengan fins maupun kolektor surya dengan $v$-corrugated absorber.

Ekadewi et al [12], menyatakan bahwa kolektor surya tipe v-corrugated absorber plate menggunakan obstacle yang ditekuk secara vertikal dapat meningkatkan kinerja. Pada penelitiannya Ekadewi et al [12] menggunakan plat penyerap berbentuk v-corrugated dimana dibawah plat penyerap didalam laluan udara ditambahkan obstacle berbentuk delta, upaya peningkatan koefisien konveksi dengan meningkatkan turbulensi aliran dalam plat penyerap adalah gabungan plat $v$-corrugated absorber dengan ditambahkan obstacle yang ditekuk vertikal dengan sudut $30^{\circ}$. Hasil yang didapatkan bahwa sudut tekuk optimal pada sudut $30^{\circ}$ memberikan rasio penurunan tekanan dibanding efisiensi yang paling tinggi $(\Delta \mathrm{P} / \Delta E f f)$. Penggunaan $v$-corrugated absorber plate dan penambahan obstacle terbukti dapat meningkatkan kofisien perpindahan panas kolektor surya. Sahiti et al [13] melakukan penelitian tentang perbandingan performansi berbagai luasan pin fins yang disusun secara duct dengan jenis pin fins dipilih karena memiliki nilai koefisien perpindahan panas lebih besar dibandingkan bentuk lainnya, penelitian ini dilakukan untuk mengetahui pengaruh bentuk modifikasi pin fins terhadap pressure drop dan kemampuan memindahkan panas, ada enam luasan pin fin yang diuji secara numerik diantaranya secara Naca, dropfoam, lancet, elliptic, circular dan square, dua bagian susunan pin fins yang dilakukan yaitu staggered dan inline. Parameter untuk geometri bentuk pin fins digunakan FCC (Frist Comparastion Criteria) yaitu diameter hidrolik, coverage ratio (ratio dari luasa pin fins dan luas bare plate) dan panjang pin konstan, hasil yang diperoleh dari penelitian ini didapatkan performansi pin fins dengan membandingkan nilai perpindahan panas perluasan base (qb) dan power input perluasan base (əb) dengan panjang pin fins yang sama, power input perluasan base menunjukkan besar volume flow rate yang masuk.

Masalah terbesar yang dihadapi kolektor surya pemanas udara yaitu rendahnya koefisien perpindahan kalor konveksi antara permukaan plat penyerap dengan udara yang mengalir dan menjadi masalah pada kolektor surya pemanas udara. Fenomena ini telah mendorong banyak penelitian berupa untuk meningkatkan efisiensi kolektor surya pemanas udara, kelebihan dari udara adalah udara lebih ringan dan tidak bersifat korosif jika dibandingkan dengan air. Udara dapat digunakan secara langsung untuk proses pengeringan, misalnya pengeringan hasil pertanian, ikan, dan lain-lain.

Dari beberapa penelitian di atas, muncul permasalahan yang akan diteliti mengenai kolektor surya pemanas udara $v$-corrugated absorber dengan obstacle dengan penambahan fins berbentuk setengah silinder yang disusun secara staggered di bawah plat penyerap dengan tujuan mengetahui diameter fins yang optimum serta jarak fins terhadap obstacle yang optimum. Skema penelitian 
kolektor surya dengan plat penyerap v-corrugated dan obstacle dengan penambahan fins yang disusun secara staggered.

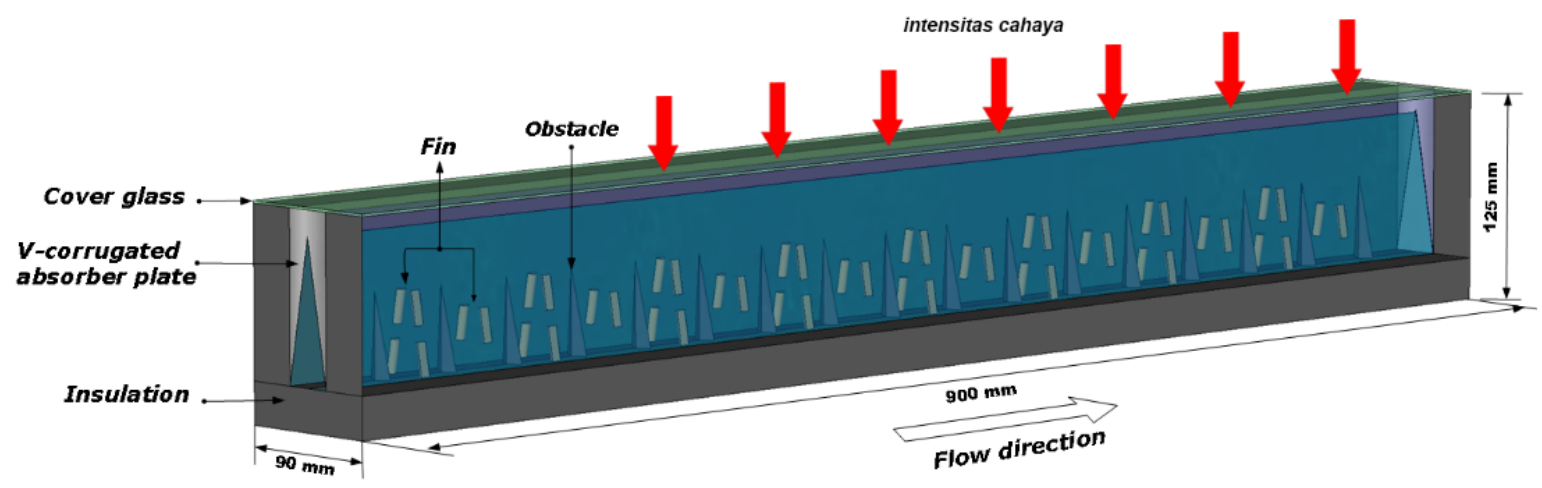

Tampak Atas

Flow direction

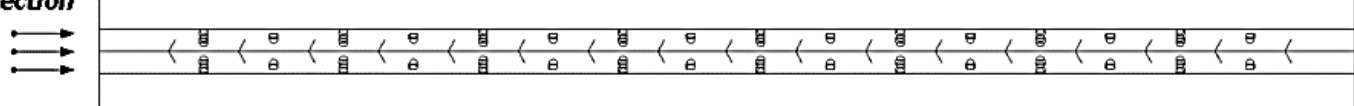

Gambar 1. Skema kolektor surya pemanas udara v-corrugated absorber dan obstacle dengan penambahan fins berbentuk setengah silinder disusun secara staggered

\section{METODE PENELITIAN}

Penelitian ini dilakukan pada kolektor surya pemanas udara dengan plat penyerap $v$-corrugated dan obstacle dengan penambahan fins setengah silinder. Penelitian ini difokuskan pada variasi diameter fins setengah silinder yang disusun secara staggered dan jarak fins dengan obstacle. Penelitian kolektor surya ini memiliki obstacle sebanyak 17 buah dan fins setengah silinder yang disusun secara staggered untuk meningkatkan efisiensi dibandingkan dengan kolektor surya yang mempunyai obstacle dengan sudut paruh $30^{\circ}$. Hasil variasi diameter setengah silinder dan jarak fins terhadap obstacle diharapkan dapat memperoleh peningkatan temperatur outlet yang signifikan. Diameter fins dalam penelitian ini yang digunakan yaitu diameter 6, 8 dan $10 \mathrm{~mm}$, jarak fins terhadap obstacle divariasikan yaitu 0,25 L; 0,5 L; 0,75 L dan L adalah jarak antar obstacle yaitu $50 \mathrm{~mm}$. Adapun dimensi obstacle dan ukuran fins yang disusun secara staggered pada kolektor surya pemanas udara v-corrugated dapat dilihat pada Gambar 2.
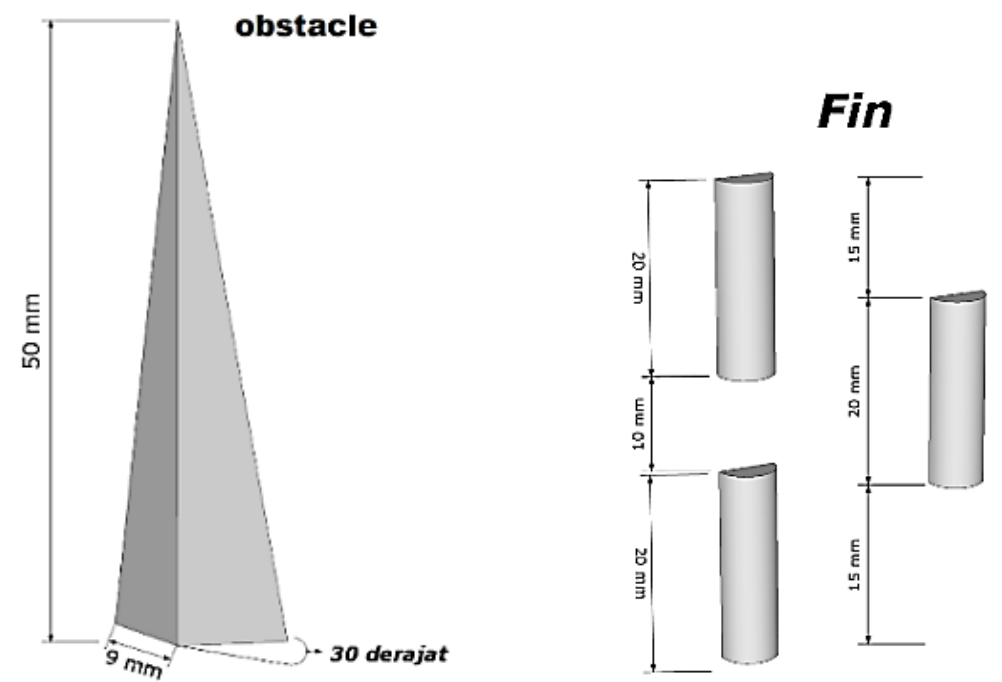

Gambar 2. Obstacle dan Fins yang digunakan pada kolektor surya 
Simulasi ini menggunakan perangkat lunak Computational Fluid Dynamics (CFD) dengan software Ansys 15.0 komersial dengan menggunakan metode diskritisasi second order upwind. Simulasi dilakukan dengan asumsi aliran berupa aliran incompressible, steady dan 3 dimensi. Untuk menganalisa karakteristik aliran yang melintasi ducting pada kolektor surya v-corrugated terdapat tahapan yang dilakukan yaitu tahap permodelan CFD. Simulasi CFD pada aliran yang melintasi ducting kolektor surya $v$-corrugated dengan penambahan fins dan obstacle ini meliputi tahap Pre-processing, processing dan post-processing. Tahap pre-processing merupakan tahap awal untuk menganalisa pemodelan CFD. Tahap ini terdiri dari pembuatan geometri, meshing dan penentuan kondisi batas. Tahapan dalam pre-processing menggunakan software ICEM. Pembuatan mesh elemen hingga (meshing) adalah pembagian model solid menjadi elemen-elemen kecil sehingga kondisi batas dan beberapa parameter yang diperlukan dapat diaplikasikan ke dalam elemen-elemen tersebut. Karena keakuratan simulasi bergantung pada grid yang dibuat, sehingga dilakukan grid independent test. Shear-Stress-Transport (SST) k- $\omega$ pada kecepatan 6,5 m/s. Pada penelitian terdahulu Ekadewi et al [12] menggunakan model $\mathrm{SK} \varepsilon$, RKe, SK $\omega$ dan SSTk $\omega$. Tipe kondisi batas dari model inlet dipilih velocity inlet. Sedangkan outlet dipilih outflow. Dinding atas dan bawah dipilih wall, kemudian fins dan obstecle masing-masing didefinisikan sebagai wall. Pada geometri yang telah dilakukan, kemudian melakukan pembuatan meshing, sebelum pembuatan mesh elemen hingga (meshing) adalah pengambilan elemen kecil sehingga kondisi batas dan beberapa parameter yang diperlukan dapat diaplikasikan kedalam elemen tersebut.

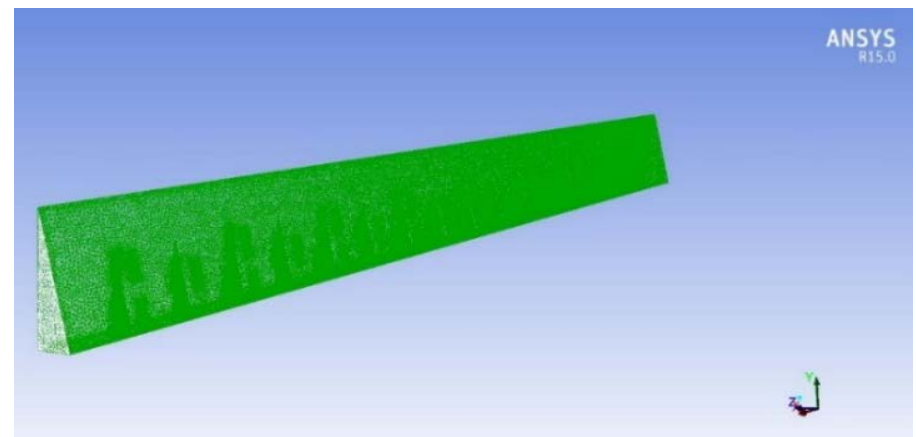

Gambar 3. Rancangan mesh dengan fins $6 \mathrm{~mm}$ dan jarak 0,25L yang digunakan dalam simulasi numerik

Tahap selanjutnya yaitu processing, merupakan langkah kedua dalam melakukan simulasi numerik dengan Computation Fluid Dynamics (CFD). Langkah-langkah yang dilakukan meliputi: memilih solver, model turbulensi, sifat material yang digunakan, menentukan kondisi batas, mengatur parameter control solusi, melakukan iterasi dan menyimpan hasil iterasi. Post-processing proses ini merupakan proses akhir dari simulasi dimana hasil simulasi berupa data kualitatif dan kuantitatif, data kualitatif berupa visualisasi aliran dan kontur kecepatan, data kuantitatif berupa temperatur, pressure dan velocity.

Grid independency pada simulasi ini yaitu bertujuan untuk memeriksa jumlah grid yang digunakan dan untuk menentukan mesh yang baik serta efisiensi yang dilakukan untuk pengamatan numerik. Grid independency pada simulasi ini menggunakan 6 variasi mesh yang berpengaruh pada jumlah cell, face dan node. Setiap mesh di uji dengan kondisi batas dan pengaturan yang sama dalam software Fluent, pengaturan yang dilakukan adalah 3 dimensi, double precision, model viscous yang digunakan adalah Shear Sress Transport k-omega (SSTk $\omega)$, material plat penyerap, plat bawah, obstacle dan fins adalah Aluminium, fluida adalah udara dengan densitas, viskositas, dan konduktivitas termal yang berubah terhadap temperatur. Kecepatan di inlet ditetapkan sama dengan kecepatan aliran dalam saluran kolektor yaitu sebesar $6,5 \mathrm{~m} / \mathrm{s}$ dengan temperatur inlet 300 K. Setelah dilakukan grid indepedency didapatkan mesh terbaik yang ditampilkan pada Tabel 1. untuk masing-masing variasi. 
Tabel 1. Jumlah cell, face dan node dari mesh yang diuji.

\begin{tabular}{|c|c|c|c|c|c|}
\hline No & Variasi & \multicolumn{2}{|c|}{ Mesh Size } & $\begin{array}{c}\text { Velocity } \\
(\mathrm{m} / \mathrm{s})\end{array}$ & $\begin{array}{c}\text { Error } \\
(\%)\end{array}$ \\
\hline \multirow{3}{*}{1} & \multirow{3}{*}{ Mesh A (Coarsen) } & Nodes & 436244 & \multirow{3}{*}{6,79} & \multirow{3}{*}{100,00} \\
\hline & & Faces & 4464706 & & \\
\hline & & Cell & 2164065 & & \\
\hline \multirow{3}{*}{2} & \multirow{3}{*}{ Mesh B (Coarse) } & Nodes & 545766 & \multirow{3}{*}{7,93} & \multirow{3}{*}{16,79} \\
\hline & & Faces & 5478900 & & \\
\hline & & Cell & 4674879 & & \\
\hline \multirow{3}{*}{3} & \multirow{3}{*}{ Mesh C (Moderate) } & Nodes & 659078 & \multirow{3}{*}{8,03} & \multirow{3}{*}{1,26} \\
\hline & & Faces & 6423402 & & \\
\hline & & Cell & 5808209 & & \\
\hline \multirow{3}{*}{4} & \multirow{3}{*}{ Mesh D (Fine) } & Nodes & 697909 & \multirow{3}{*}{8,17} & \multirow{3}{*}{1,74} \\
\hline & & Faces & 6998790 & & \\
\hline & & Cell & 6590876 & & \\
\hline \multirow{3}{*}{5} & \multirow{3}{*}{ Mesh E (Finest) } & Nodes & 767898 & \multirow{3}{*}{8,57} & \multirow{3}{*}{4,90} \\
\hline & & Faces & 7809789 & & \\
\hline & & Cell & 7098794 & & \\
\hline
\end{tabular}

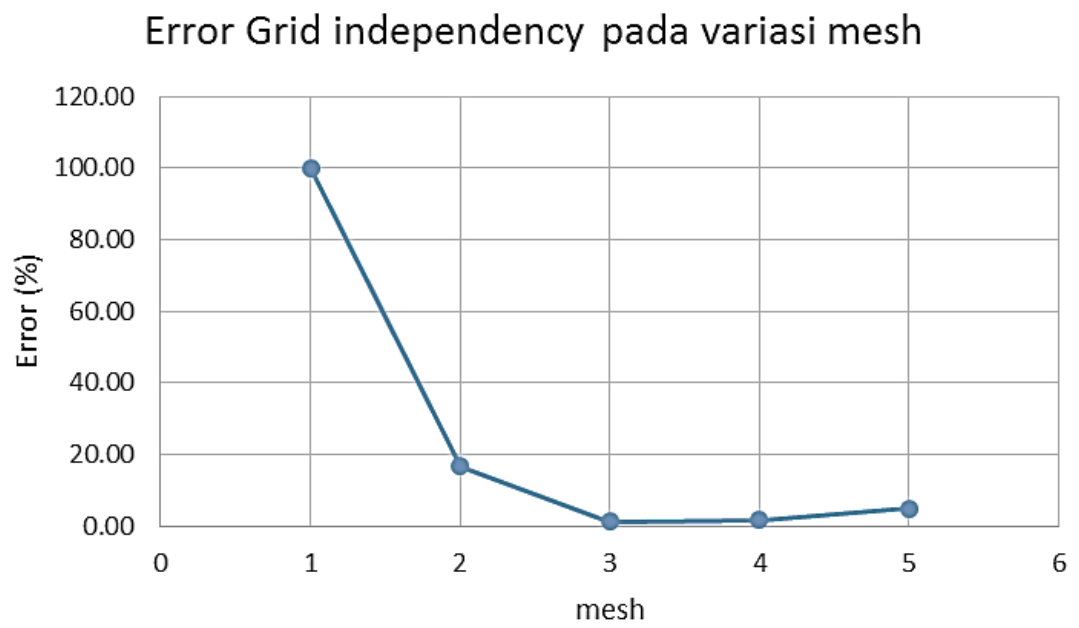

Gambar 4. Nilai error grid independency

Dari Gambar 4 didapatkan mesh 3 yang memiliki error yang tidak banyak berubah dibandingkan dengan mesh 4, mesh 5, maka mesh 3 dianggap memenuhi grid independency.

\section{HASIL DAN PEMBAHASAN}

Penelitian ini dilakukan dengan simulasi numerik, untuk membandingkan performa kolektor surya dengan penambahan fins dan tanpa fins. Sebelum melakukan percobaan dilakukan pengujian dimensi fins yang paling optimum menggunakan simulasi numerik. Adapun variasi dimensi fins terletak pada diameter fins $6 \mathrm{~mm}, 8 \mathrm{~mm}$ dan $10 \mathrm{~mm}$ dan jarak fins terhadap obstacle yaitu 0,25L; 0,50L dan 0,75L. Setelah mengetahui diameter dan jarak fins yang paling optimum berdasarkan perubahan suhu dan penurunan tekanan, kemudian penelitian ini dilanjutkan ke eksperimen terhadap performa kolektor surya pemanas udara. Hasil simulasi numerik didapatkan yang ditampilkan pada Tabel 2. Intensitas cahaya yang digunakan pada simulasi ini adalah $430 \mathrm{Watt} / \mathrm{m}^{2}$ dengan kecepatan fluida masuk sebesar $6,5 \mathrm{~m} / \mathrm{s}$. Keluaran yang didapat dari simulasi ini adalah peningkatan temperatur dan penurunan tekanan. Simulasi yang dilakukan pada saluran tanpa fins juga dilakukan untuk membandingkan pengaruh fins terhadap peningkatan temperatur dan penurunan tekanan. 
Tabel 2. Perbedaan temperatur dan tekanan hasil simulasi pada semua variasi fins

\begin{tabular}{|c|c|c|c|c|c|c|}
\hline Variasi Fins & $\mathrm{L}$ & $\Delta \mathrm{P}(\mathrm{Pa})$ & $\Delta \mathrm{T}(\mathrm{K})$ & Rasio $\Delta \mathrm{P}$ & Rasio $\Delta \mathrm{T}$ & $\begin{array}{c}\text { Rasio } \Delta \mathrm{P} / \\
\Delta \mathrm{T}\end{array}$ \\
\hline \multirow{3}{*}{6} & 0,25 & 365,9 & 9,5543 & 0,841269 & 0,031665 & 26,56789 \\
\hline & 0,5 & 349,8 & 9,6459 & 0,760251 & 0,041556 & 18,29472 \\
\hline & 0,75 & 327 & 9,7409 & 0,645518 & 0,051814 & 12,45837 \\
\hline tanpa fins & & 198,7217 & 9,26105 & & & \\
\hline \multirow{3}{*}{8} & 0,25 & 924,7 & 11,4766 & 3,653242 & 0,239233 & 15,27064 \\
\hline & 0,5 & 773,5 & 11,0109 & 2,892379 & 0,188947 & 15,30786 \\
\hline & 0,75 & 791,1 & 11,2118 & 2,980945 & 0,21064 & 14,15183 \\
\hline tanpa fins & & 198,7217 & 9,26105 & & & \\
\hline \multirow{3}{*}{10} & 0,25 & 1056,6 & 10,8331 & 4,316985 & 0,169749 & 25,43164 \\
\hline & 0,5 & 835,5 & 10,7922 & 3,204373 & 0,165332 & 19,38142 \\
\hline & 0,75 & 848,5 & 11,3773 & 3,269791 & 0,228511 & 14,30913 \\
\hline tanpa fins & & 198,7217 & 9,26105 & & & \\
\hline
\end{tabular}

Pemilihan fins yang optimal didasarkan pada kenaikan temperatur dan penurunan tekanan yang dirumuskan secara matematis yaitu:

$$
\mathrm{R}=\frac{\Delta P=\left|\frac{\Delta P_{\text {tanpa fin }}-\Delta P_{\text {fin }}}{\Delta P_{\text {tanpa fin }}}\right|}{\Delta T=\left|\frac{\Delta T_{\text {tanpa fin }}-\Delta T_{\text {fin }}}{\Delta T_{\text {tanpa fin }}}\right|}
$$

Nilai dari perbedaan tekanan dan temperatur yang dihasilkan dari setiap variasi fins dibandingkan dengan nilai perbedaan tekanan dan temperatur pada saluran tanpa fins. Nilai rasio $(\Delta \mathrm{P} / \Delta \mathrm{T})$ yang diharapkan dari hasil simulasi adalah nilai terkecil. Setelah dilakukan simulasi pada semua variasi tersebut didapatkan hasil fins dengan diameter $6 \mathrm{~mm}$ dan jarak fins terhadap obstacle 0,75L. Fins yang paling optimal dengan nilai $\Delta \mathrm{P} / \Delta \mathrm{T}=12.45837$. Adapun proses simulasi yang dilakukan yaitu untuk mengetahui distribusi temperatur pada setiap diameter fins dan jarak fins terhadap obstacle, mulai dari fins $6 \mathrm{~mm}, 8 \mathrm{~mm}$ dan $10 \mathrm{~mm}$ dengan jarak fins terhadap obstacle 0,25L; 0,5L dan 0,75L, seperti pada Gambar 5, Gambar 6 dan Gambar 7.

Pada Gambar 5, Gambar 6 dan Gambar 7, distribusi temperatur dari diameter fins 6 mm, $8 \mathrm{~mm}$ dan $10 \mathrm{~mm}$ dengan jarak fins terhadap obstacle 0,25L; 0,5L dan 0,75L menunjukkan, dengan penambahan fins dalam saluran ducting kolektor surya $v$-corrugated absorber, akan meningkatkan temperatur dengan laju aliran yang ditetapkan $6,5 \mathrm{~m} / \mathrm{s}$ dan temperatur inlet $\left(\mathrm{T}_{\mathrm{fin}}\right)=300 \mathrm{~K}$.

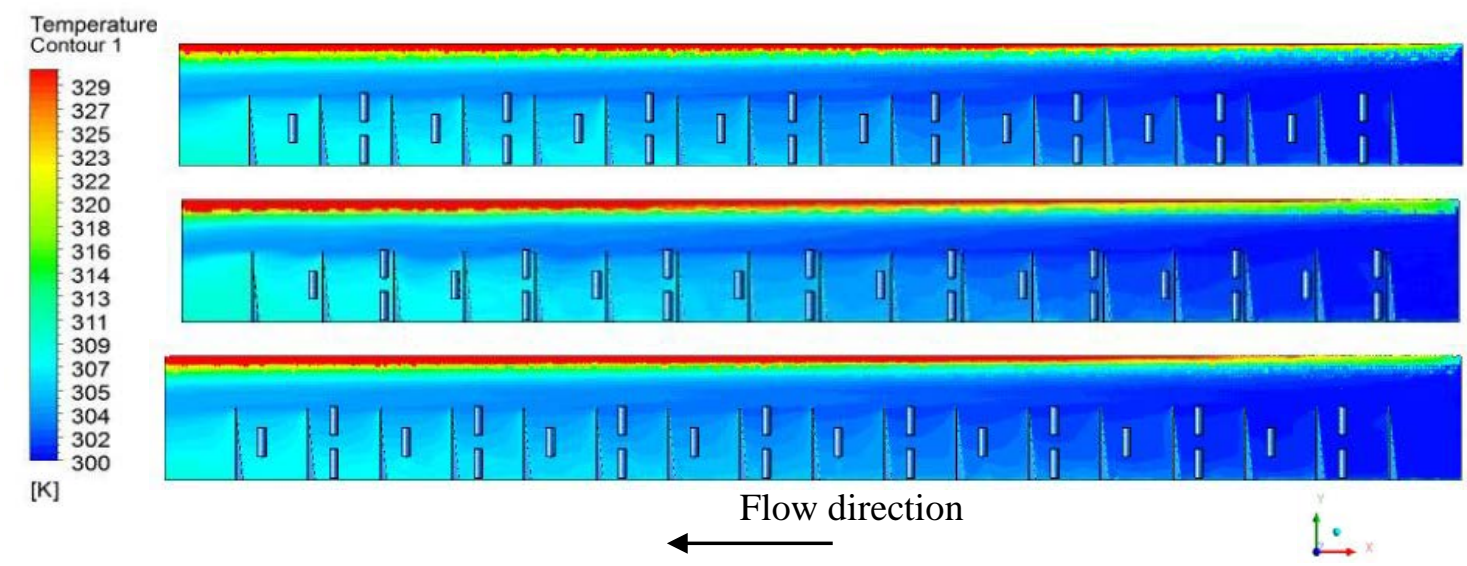

Gambar 5. Distribusi temperatur pada diameter fins $6 \mathrm{~mm}$ dengan jarak fins terhadap obstacle (a) Fins 6 mm jarak 0,25L, (b) Fins 6 mm jarak 0,5L dan (c) Fins 6 mm jarak 0,75L 


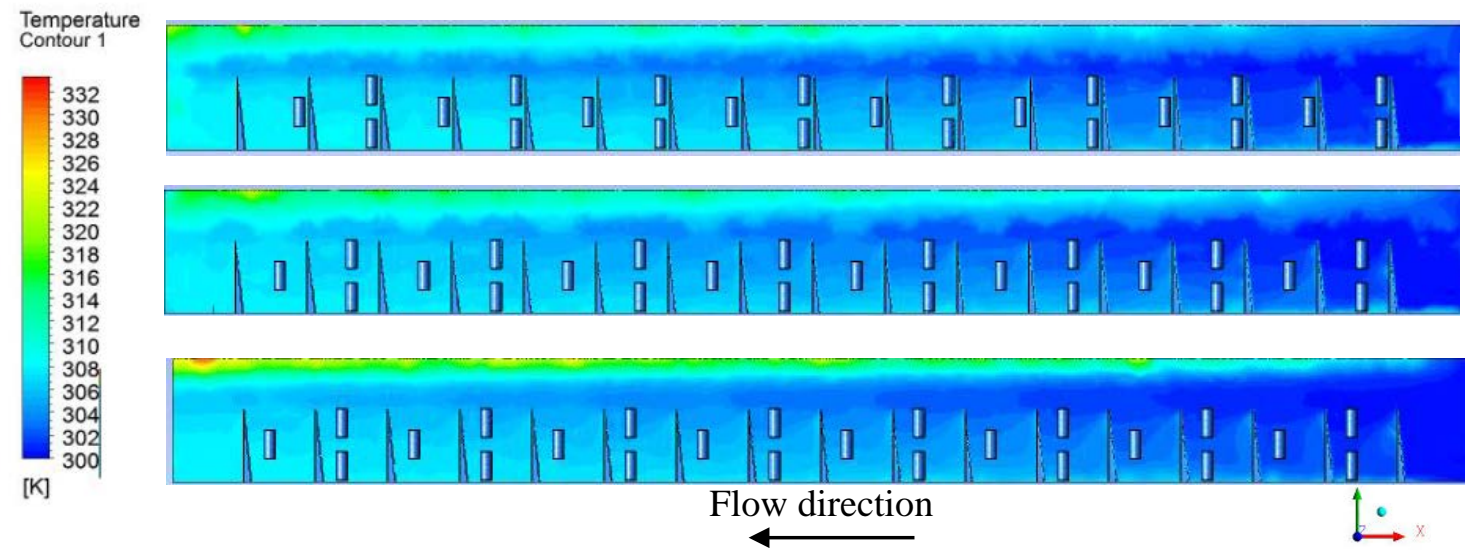

Gambar 6. Distribusi temperatur pada diameter fins $8 \mathrm{~mm}$, dengan jarak fins terhadap obstacle (a) Fins 8 mm jarak 0,25L, (b) Fins 8 mm jarak 0,5L dan (c) Fins 8 mm jarak 0,75L

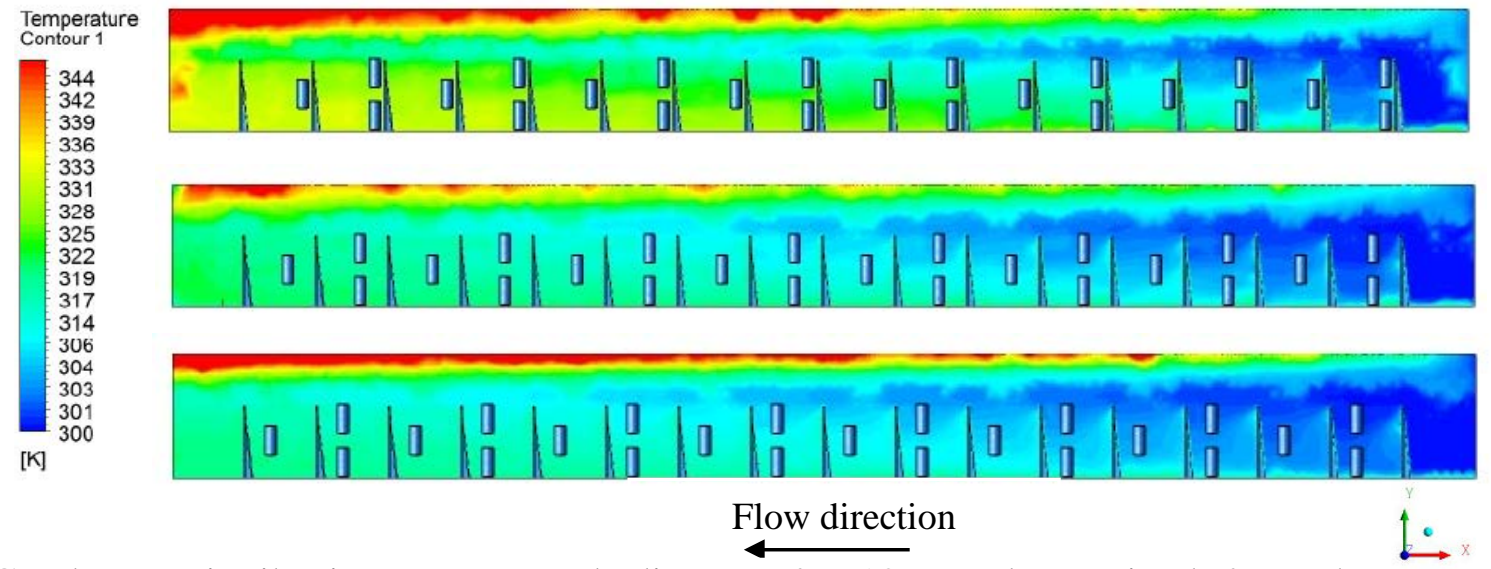

Gambar 7. Distribusi temperatur pada diameter fins $10 \mathrm{~mm}$, dengan jarak fins terhadap obstacle

(a) Fins $10 \mathrm{~mm}$ jarak 0,25L, (b) Fins $10 \mathrm{~mm}$ jarak 0,5L dan (c) Fins $10 \mathrm{~mm}$ jarak 0,75L

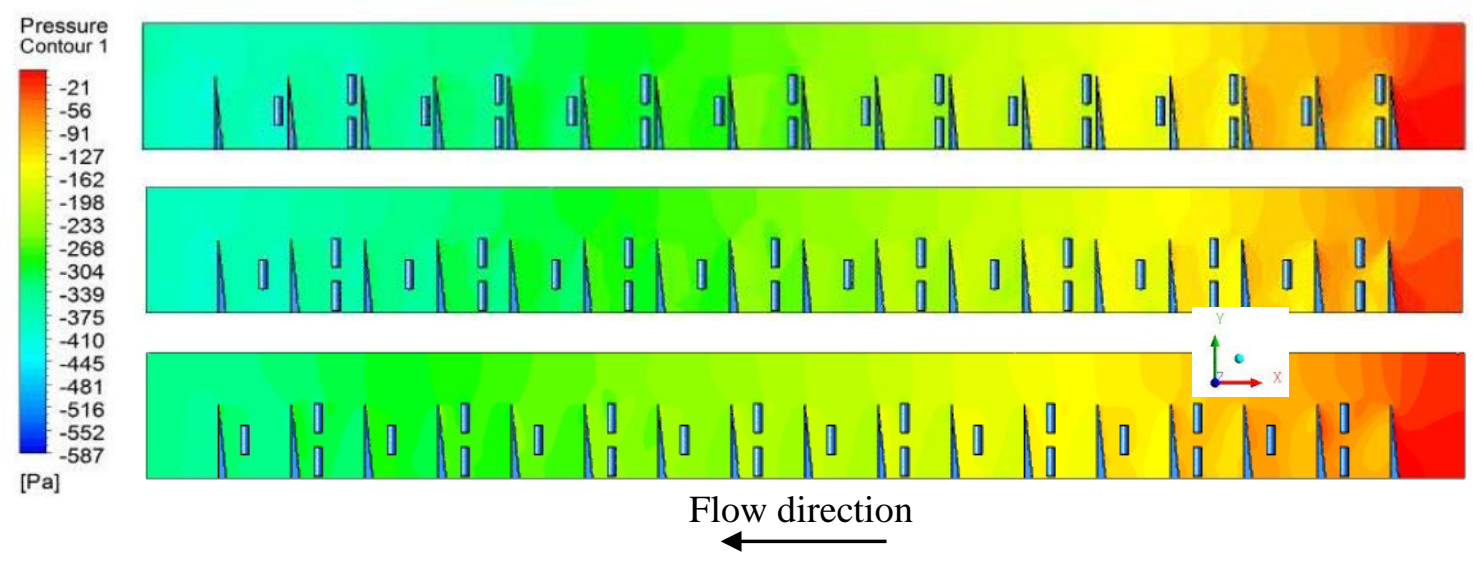

Gambar 8. Distribusi tekanan (Pressure) pada diameter fins $6 \mathrm{~mm}$ dengan semua jarak fins terhadap obstacle (a) Fins $6 \mathrm{~mm}$ jarak 0,25L, (b) Fins $6 \mathrm{~mm}$ jarak 0,5L dan (c) Fins $6 \mathrm{~mm}$ jarak 0,75L

Pada proses simulasi ini dilakukan juga, untuk mengetahui hasil distribusi tekanan (Pressure) pada diameter fins $6 \mathrm{~mm}, 8 \mathrm{~mm}$ dan $10 \mathrm{~mm}$ dengan jarak fins terhadap obstacle yaitu 0,25L; 0,5L dan 0,75L. Pada Gambar 8, distribusi tekanan (Pressure) dari diameter fins $6 \mathrm{~mm}$ dengan jarak fins terhadap obstacle 0,25L; 0,5L dan 0,75L menunjukkan bahwa dengan penambahan obstacle dan fins dalam ducting solar kolektor pemanas udara mengakibatkan 
penurunan tekanan terjadi secara bertahap, pada aliran fluida memasuki ke dalam ducting, tekanan terjadi tinggi, kemudian setelah melewati obstacle dan fins, tekanan semakin kecil.

Pada Gambar 9 menunjukkan streamline kecepatan yang dihasilkan dari fins diameter $6 \mathrm{~mm}$ dan jarak terhadap obstacle 0,75L. Rasio yang diharapkan yakni dengan nilai terkecil dengan penurunan tekanan terkecil dan peningkatan temperatur terbesar.

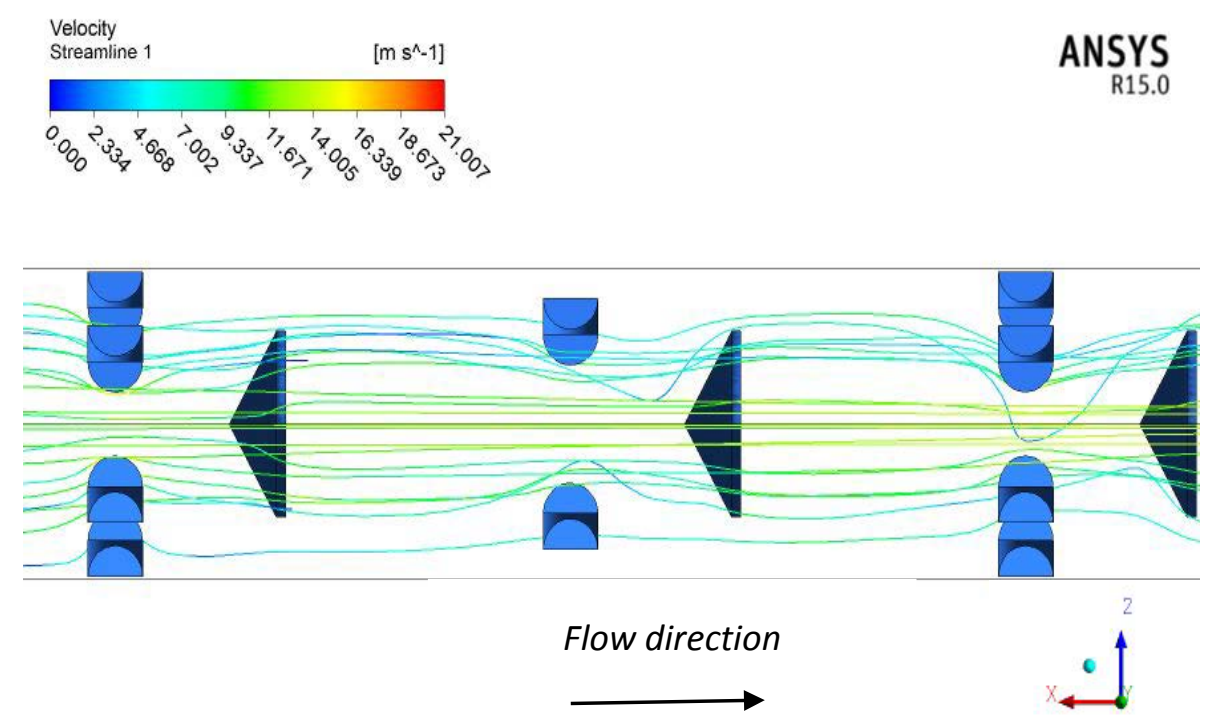

Gambar 9. Streamline kecepatan pada fins $6 \mathrm{~mm}$ dan jarak terhadap obstacle 0,75L

\section{SIMPULAN}

Dari penelitian yang telah dilakukan pada kolektor surya v-corrugated absorber dengan penambahan obstacle dan fins berbentuk setengah silinder yang disusun secara staggered yaitu berdasarkan hasil simulasi numerik, fins berbentuk setengah silinder yang paling optimum adalah fins dengan diameter $6 \mathrm{~mm}$ dan jarak terhadap obstacle sebesar $0,75 \ell$ dengan beda temperatur 9,7409 K dan penurunan tekanan sebesar $327 \mathrm{~Pa}$, dari hasil fins dan jarak fins terhadap obstacle yang terbaik dilanjutkan penelitian ini ke eksperimen.

\section{DAFTAR PUSTAKA}

[1]. Sudirman S., 2014, Indonesia Outlook Energy, BPPT ESDM, Indonesia.

[2]. Islamoglu Y., Parmaksizoglu C., 2003, The Effect of Channel Height on the Enhanced Heat Transfer Characteristics in a Corrugated Heat Exchanger Channel, Vol.23, Hal: 979-987, Applied Thermal Engineering Journal.

[3]. El-Sebaii A., Enein S.A., Ramadan M.R.I., Shalaby S.M., Moharram B.M., 2011, Investigation of Thermal Performance of Double Pass-flat and V-corrugated Plate Solar Air Heaters, Vol.36, Hal: 1076-1086, Energy Journal.

[4]. Naphon P., 2007, Heat Transfer Characteristics and Pressure Drop in Channel with V-corrugated Upper and Lower Plates, Energy Conversion and Management Journal, Vol.48, Hal: 1516-1524,.

[5]. Peng D., Zhang X., Dong H., Lv K., 2010, Performance Study of a Novel Solar Air Collector, Applied Thermal Engineering Journal, Vol.30, Hal: 2594-2601.

[6]. Bekele A., Mishra M., Sushanta Dutta, 2014, Performance Characteristics of Solar Air Heater with Surface Mounted Obstacles, Energy Conversion and Management Journal, Vol.85, Hal 603-611.

[7]. Ho C.D., Yeh H.M., Cheng T.W., Chen T.C., Wang R.C., 2009, The Influences of Recycle on Performance of Baffled Double-pass Flat-plate Solar Air Heaters with Internal Fins Attached, Applied Energy Journal, Vol.86, Hal: 1470-1478. 
[8]. Kulkarni K., Afzal A., Kim K-Y., 2015, Multi-objective Optimization of Solar Air Heater with Obstacles on Absorber Plate, Solar Energy, Vol 114, Hal 364-377.

[9]. Kurtsbas, Turgut, 2006, Experimental Investigation of Solar Air Heater with Free and Fixed Fins: Efficiency and Exergy Loss, International Journal of Science \& Technology, Vol. 1. Hal: 75-82.

[10]. Randall. K.R., B.A. Meyer, M.M. El-Wakil, J.W. Mitchell, 1978, Interferometric Investigation of Convection in Slat, Flat plate, and V-corrugated Solar Collectors, USA, University of Wisconsin-Madison.

[11]. Karim M.A., Hawlader M.N.A., 2006, Performance Investigation of Flat Plate, V-corrugated and Finned Air Collectors, Energy Journal, Vol.31, Hal: 452-470.

[12]. Ekadewi S. H., Djatmiko Ichsani, Prabowo, Sutardi, 2014, Peningkatan Kinerja Kolektor Surya V-Corrugated Absorber Plate Menggunakan Obstacle yang Ditekuk Secara Vertikal, ITS, Surabaya.

[13]. Sahiti N., Lemouedda A., Stojkovic D., Durst F., Franz E., 2006, Performance Comparison of Pin Fin In-Duct Flow Arrays with Various Pin Cross-Sections, International Journal of Science \& Technology, Vol.26, Hal:1176-1192. 